\title{
Cleaner production of carbon adsorbents by utilizing agricultural waste corn cob
}

\author{
W.T. Tsai ${ }^{\text {a,* }}$, C.Y. Chang b, S.Y. Wang b, C.F. Chang ${ }^{\mathrm{b}}$, \\ S.F. Chien ${ }^{\text {a }}$, H.F. Sun ${ }^{\text {a }}$ \\ a Department of Environmental Engineering and Health, Chia Nan University of Pharmacy and Science, \\ Tainan 717, Taiwan, ROC \\ ${ }^{\mathrm{b}}$ Graduate Institute of Environmental Engineering, National Taiwan University, Taipei 106, Taiwan, \\ $R O C$
}

Received 14 April 2000; accepted 13 October 2000

\begin{abstract}
In the present study, the porous carbon products from agricultural waste corn cob were manufactured by using the combined activation methods. Under the experimental conditions in the activation temperature ranges of $500-800^{\circ} \mathrm{C}$ with less pollution characteristics of potassium hydroxide/potassium carbonate $\left(\mathrm{KOH} / \mathrm{K}_{2} \mathrm{CO}_{3}\right)$ as chemical agents and subsequent gasification (i.e. physical activation) at the soaking time of $1 \mathrm{~h}$, the influence of activation temperature on the final products was studied by examining their physical characterizations such as BET surface area, total pore volume and true density. The experimental results show that an elevated temperature is favorable for producing carbon products with high surface area and total pore volume. Also, the values of the true density and the porosity increase with increase in the activation temperature. Comparing the results of physical characterizations of the carbon products with those of commercial activated carbons indicates that the activated carbons prepared from agricultural waste corn cob by using a cleaner process is an available route for the biomass utilization and bioresource recycling. The high-surface-area carbon products thus obtained are very promising adsorbents for pollution control and for other applications. (C) 2001 Elsevier Science B.V. All rights reserved.
\end{abstract}

Keywords: Corn cob; Activation; Activated carbon; Characterization; Resource recycling

* Corresponding author. Tel.: + 886-6-2660393; fax: + 886-6-2667323.

E-mail address: wwtsai@mail.chna.edu.tw (W.T. Tsai).

0921-3449/01/\$ - see front matter (C) 2001 Elsevier Science B.V. All rights reserved.

PII: S0921-3449(00)00093-8 


\section{Introductionf}

Residues from agriculture and agro-industries are the non-product outputs from the growing and processing of raw agricultural products such as rice, corn, bean, and peanut. While such residues may contain valuable materials, their current economic values are less than the apparent cost of collection, transportation and processing for beneficial use. Therefore, they are often discharged as wastes. In Taiwan, during the 1980s the expansion of corn plantations was encouraged by the governmental policy, inevitably followed by the generation of large amounts of agricultural waste corn cob due to the approximate $18 \mathrm{~kg}$ of corn cob per $100 \mathrm{~kg}$ of corn grain production (Bagby and Widstrom, 1987). Many approaches for processing corn cob were as fertilizers and soil conditioners by land application, as animal and poultry bedding, as fiber and roughage in animal feed (Bagby and Widstrom, 1987); as energy source by combustion (Lin et al., 1995); as biological substrate for the production of forage protein (Perotti and Molina, 1988) and furfural (Mckillip and Sherman, 1980). However, the utilization of this agricultural waste as raw material for the preparation of activated carbon has increased notably in recent years (Aggarwal and Dollimore, 1997; Tsai et al., 1997; Chang et al., 1998; Tsai et al., 1998).

Over the last few decades, adsorption has gained importance as a purification, recovery and separation process on an industrial scale. For recovery purposes, adsorption has been applied to recover some biological materials and organic compounds from both aqueous and gaseous streams as well as precious metals, e.g. gold in mines (Noll et al., 1992; Al-Duri, 1996). Activated carbon is perhaps one of the most widely used adsorbents in industry. Commercial carbon adsorbents are produced from organic materials that are cheap with a high carbon content and low in inorganics or ash, particularly coal, coconut shell, wood, peat and lignite (Bansal et al., 1988). Despite the extensive use of carbon adsorbent throughout liquid- and gas-phase applications, carbon adsorption technology is still an expensive process. Over recent years, this has prompted a growing research interest into the low-cost alternatives for the production of activated carbon from agricultural wastes or by-products (Pollard et al., 1992; Heschel and Klose, 1995; Tsai et al., 1998). Hence, their reuses as secondary adsorbents contribute to the waste minimization strategy being placed on recycling and recovery.

The high adsorptive capacities of activated carbons are related to properties such as surface area, pore volume and porosity. These unique characteristics are dependent on the type of raw materials employed and the method of activation. Basically, the process for manufacturing activated carbons involves two steps, the carbonization of raw carbonaceous materials in an inert atmosphere and the chemical/physical activation of carbonized product (Al-Duri, 1996). Chemical activation is performed in one stage, combining carbonization with activation, by using a dehydrating agent such as zinc chloride $\left(\mathrm{ZnCl}_{2}\right)$, phosphoric acid $\left(\mathrm{H}_{3} \mathrm{PO}_{4}\right)$ and potassium salts. Physical activation, on the other hand, involves the carbonization of a carbonaceous precursor followed by activation of the resulting char in the presence of some activating gases such as $\mathrm{CO}_{2}$ or steam. Among the numerous 
dehydrating agents for chemical activation, $\mathrm{ZnCl}_{2}$ and $\mathrm{H}_{3} \mathrm{PO}_{4}$ are the most widely used chemical agents (Jankowska et al., 1991; Ahmadpour and Do, 1996). However, the use of $\mathrm{ZnCl}_{2}$ and $\mathrm{H}_{3} \mathrm{PO}_{4}$ has been limited recently due to the problems of possible environmental contamination and eutrophication with zinc and phosphorus compounds, respectively (Jankowska et al., 1991).

In the earlier studies (Tsai et al., 1997, 1998), the preparation of activated carbons from agricultural waste corn cob through chemical activation with $\mathrm{ZnCl}_{2}$ has been extensively studied. The results have shown that activated carbons with high surface area can be obtained only at about $500^{\circ} \mathrm{C}$ and a high impregnation ratio. Also, the activation temperature is a very important parameter, which had a significant effect on the pore surface area evolution. The preparation and the properties of activated carbons from potassium salts activation have not been thoroughly compared with those from $\mathrm{ZnCl}_{2}$ and $\mathrm{H}_{3} \mathrm{PO}_{4}$ activation, when corn cob is used as the starting material. Also noted is that studies on the combination of chemical and physical activation is not common in the literature. For a preliminary study, the aim of this work is to describe the feasibility on the preparation of activated carbons from agricultural waste corn cob by chemical activation with potassium hydroxide $(\mathrm{KOH})$ and potassium carbonate $\left(\mathrm{K}_{2} \mathrm{CO}_{3}\right)$ due to their less toxic properties. Subsequent physical activation of resulting carbons with $\mathrm{CO}_{2}$ was attempted to obtain activated carbon with high surface area. The main physical and chemical characteristics of resulting activated carbons were analyzed and examined to compare with those of commercial activated carbons.

\section{Materials and methods}

\subsection{Materials}

The carbonaceous precursor used in the study is corn cob, a waste product from the production of corn plant. The Taiwanese corn cob was crushed to free from the pitch and light chaff, and then sieved to mesh range of $12 \times 16$ (diameter of granule, $1.19-1.68 \mathrm{~mm}$ ). The main parts (i.e. woody ring and coarse chaff) of corn cob were used for their utilization in the production of activated carbons due to their physical properties (Tsai et al., 1997; Chang et al., 1998; Tsai et al., 1998). The compositions of raw material in weight percent based on proximate and ultimate analyses are given in Table 1 (Chang et al., 1998; Tsai et al., 1998). The activating agents, i.e. $\mathrm{KOH}$ and $\mathrm{K}_{2} \mathrm{CO}_{3}$ were purchased from Nacalai Tesque Co. (Kyoto, Japan) with a minimum purity of 85.0 and $99.0 \%$, respectively. BPL and PCB (Calgon Co., USA), made from bituminous coal and coconut, respectively, were used as the commercial activated carbons for purposes of comparisons.

\subsection{Sample preparation}

Potassium salts $\left(\mathrm{KOH}\right.$ or $\left.\mathrm{K}_{2} \mathrm{CO}_{3}\right)$ in the form of pellets were mixed with $20 \mathrm{~g}$ of air-dried corn cob particle in $200 \mathrm{~cm}^{3}$ of distilled water using hot plate/magnetic 
stirrer. Then the impregnation was carried out at approximately $80^{\circ} \mathrm{C}$ in a boilerreflux condenser for $1-2 \mathrm{~h}$. Several impregnation ratios, defined as the ratio of the mass of potassium salt to that of corn cob, were attempted to prepare the impregnated samples for the production of carbon products by chemical activation at $800^{\circ} \mathrm{C}$. It was found that the difficulty arose, when attempting to obtain the entire carbonaceous products up to impregnation ratios of $20 \mathrm{wt} . \% \mathrm{KOH}$ and 50 wt. $\% \mathrm{~K}_{2} \mathrm{CO}_{3}$ due to the serious sintering (i.e. burn-off). Therefore, the impregnation ratios of 15 wt. $\% \mathrm{KOH}$ and $37.5 \mathrm{wt} . \% \mathrm{~K}_{2} \mathrm{CO}_{3}$ were used to prepare activated carbons with more developed porosity, because high impregnation ratio was favorable for producing carbon adsorbents with high porosity and thus high surface area (Tsai et al., 1997, 1998).

\subsection{Sample activation}

A schematic diagram of the experimental apparatus for the sample activation is identical to that for the chemical activation with $\mathrm{ZnCl}_{2}$ (Tsai et al., 1997, 1998), as shown in Fig. 1. For all experiments, the mass (approximately $10 \mathrm{~g}, W_{1}$, in each set of experiments) of the impregnated corn cob was placed in a stainless steel (S.S. 316) holder with net in the bottom, then housed at the center of a stainless steel (S.S. 316) tubular reactor of $800 \mathrm{~mm}$ in length and $50 \mathrm{~mm}$ in diameter. This reactor was placed vertically inside an electric tube furnace controlled by the proportional integral derivative (PID) controller. The temperatures of the reaction zone were measured by the chromel-alumel (K-type) thermocouples. The nitrogen gas from a cylinder was dried and purified by molecular sieve tube. The pyrolyzed samples were subjected to the specified activation temperature at a heating rate of $10^{\circ} \mathrm{C} / \mathrm{min}$ under a constant nitrogen flow rate of $200 \mathrm{~cm}^{3} / \mathrm{min}$ at standard temperature and pressure (STP). The pyrolyzed samples were then subjected to physical activation in $\mathrm{CO}_{2}$ at activation temperature for exposure time of $1 \mathrm{~h}$ before cooling under nitrogen flow. Thus, the most important parameter studied in the present paper was pyrolysis temperature of $500-800^{\circ} \mathrm{C}$.

The resulting solids after activation were weighed for their mass $\left(W_{2}\right)$. The pyrolysis yields of the crude carbon products were thus calculated by $W_{2} / W_{1}$. Then, these samples were washed at about $80^{\circ} \mathrm{C}$ with $500 \mathrm{~cm}^{3}$ of $3 \mathrm{~N} \mathrm{HCl}$ for $30 \mathrm{~min}$,

Table 1

Analysis of agricultural waste corn cob $^{\mathrm{a}}$

\begin{tabular}{lrlr}
\hline Ultimate (wt.\%) & & \\
\hline Carbon & 46.8 & Hydrogen & 6.0 \\
Nitrogen & 0.9 & Oxygen (by difference) & 46.3 \\
\hline Proximate (wt.\%, as received basis) & & 16.1 \\
Moisture & 4.3 & Fixed carbon & 0.9 \\
Volatile organics & 78.7 & Ash &
\end{tabular}

${ }^{a}$ References Chang et al. (1998) and Tsai et al. (1998). 


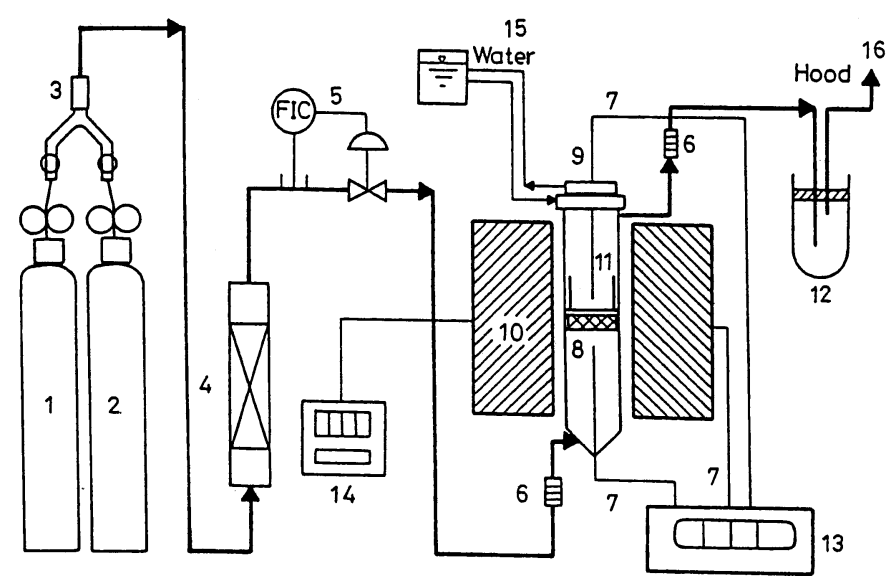

Fig. 1. Schematic diagram of experimental apparatus: (1) $\mathrm{CO}_{2}$ cylinder; (2) $\mathrm{N}_{2}$ cylinder; (3) Three-way valve; (4) Molecular sieve; (5) Mass flow controller; (6) Fast connector; (7) Thermocouple; (8) Reaction net; (9) Tubular fixed-bed reactor; (10) Heating furnace; (11) Crucible; (12) Oil collector; (13) Temperature recorder; (14) Temperature controller; (15) Cycle water system; (16) Vent to hood (Tsai et al., 1998).

filtered in a vacuum flask and washed sequentially with warm distilled water for several times to remove the salt ions and other residues. The solids were finally dried at $105^{\circ} \mathrm{C}$ for $24 \mathrm{~h}$, and stored in the desiccator after drying.

\subsection{Characterization measurements}

The nitrogen adsorption-desorption isotherms of the resulting activated carbons, used for calculating their Brunauer-Emmett-Teller (BET) surface areas and total pore volumes, were obtained by using an ASAP 2000 apparatus (Micrometerics Co., USA). The BET surface areas were assessed by applying relative pressures ranging from 0.06 to 0.2 . The total pore volumes $\left(V_{\mathrm{t}}, \mathrm{cm}^{3} / \mathrm{g}\right)$ were estimated to be the liquid volumes of $\mathrm{N}_{2}$ at a high relative pressure of 0.96 . The true density $\left(\rho_{\mathrm{s}}\right)$ of the sample was measured by a helium displacement method with a pycnometer AccuPyc 1330 (Micromeritics Co., USA) (Lowell and Shields, 1991), where the measurement was repeated ten times for each sample. The particle density $\left(\rho_{\mathrm{p}}\right)$ was thus calculated from $V_{\mathrm{t}}$ and $\rho_{\mathrm{s}}($ Smith, 1981)

$$
\rho_{\mathrm{p}}=\frac{1}{V_{\mathrm{t}}+1 / \rho_{\mathrm{s}}}
$$

Therefore, the particle porosity $\left(\varepsilon_{\mathrm{p}}\right)$ can be computed from $\rho_{\mathrm{s}}$ and $\rho_{\mathrm{p}}$.

$$
\varepsilon_{\mathrm{p}}=1-\frac{\rho_{\mathrm{p}}}{\rho_{\mathrm{s}}}
$$

Further, analyses of main elements (i.e. carbon, hydrogen, nitrogen, and oxygen thus balanced) for carbon products were performed by using a $\mathrm{CHN}-\mathrm{O}$ rapid analyzer (Heraeus Co., Germany) for two measurements. 


\section{Results and discussion}

The effects of temperature on the chemical/physical activation of activated carbons are presented in Table 2 . In the temperature ranges $\left(500-800^{\circ} \mathrm{C}\right)$ studied in this paper, it is clear that the activation temperature has a significant influence on the porosity development and thus the BET surface area obtained from the nitrogen adsorption-desorption isotherms with $-196^{\circ} \mathrm{C}$. The BET surface areas were observed to increase at higher activation temperature for both $\mathrm{KOH}$ and $\mathrm{K}_{2} \mathrm{CO}_{3}$ series. It is also seen from Table 2 that the maximum rate of increase in BET surface area occurred between 650 and $700^{\circ} \mathrm{C}$. It has been reported (Otowa et al., 1993) that at a temperature higher than $700^{\circ} \mathrm{C}$, metallic potassium is produced and they intercalated to the carbon matrix, which are responsible for further carbon gasification and release of gaseous products such as $\mathrm{CO}_{2}, \mathrm{CO}$ and $\mathrm{H}_{2}$ (Laine and Calafat, 1991).

The nitrogen adsorption isotherms of resulting activated carbons are shown in Fig. 2. It is clear that the adsorption isotherm is of type $I$ according to the Brunauer, Deming, Deming and Teller (BDDT) classification with a well-defined plateau Gregg and Sing, 1982, that is, the knee of the isotherms is sharp and the plateau is quite horizontal with no hysteresis. The major uptake occurs at low relative pressures (less than 0.1 ), indicating the formation of highly porous materials with narrow pore size distribution that are essentially microporous as shown in Fig. 3. It should be noted that the interaction potential in a microporous solid might be strongly enough to bring about a nearly complete filling of pores at a quite low relative pressure (Gregg and Sing, 1982). Also seen in Table 2, the

Table 2

List of BET surface area and pyrolysis yield of carbon products prepared from agricultural waste corn cob by chemical/physical activation

\begin{tabular}{|c|c|c|c|}
\hline \multicolumn{2}{|c|}{ Carbon products ${ }^{\mathrm{a}}$} & \multirow[t]{2}{*}{ BET surface area $\left(\mathrm{m}^{2} / \mathrm{g}\right)$} & \multirow[t]{2}{*}{ Pyrolysis yield $(\%)$} \\
\hline $\begin{array}{l}\text { Activating } \\
\text { agent }\end{array}$ & Activation temperature $\left({ }^{\circ} \mathrm{C}\right)$ & & \\
\hline $\mathrm{KOH}$ & 500 & 0.1 & 31.3 \\
\hline $\mathrm{KOH}$ & 600 & 0.1 & 30.3 \\
\hline $\mathrm{KOH}$ & 650 & 63 & 27.2 \\
\hline $\mathrm{KOH}$ & 700 & 548 & 25.7 \\
\hline $\mathrm{KOH}$ & 750 & 1004 & 22.9 \\
\hline $\mathrm{KOH}$ & 800 & 1806 & 12.8 \\
\hline $\mathrm{K}_{2} \mathrm{CO}_{3}$ & 500 & 0.2 & 33.5 \\
\hline $\mathrm{K}_{2} \mathrm{CO}_{3}$ & 600 & 6 & 30.3 \\
\hline $\mathrm{K}_{2} \mathrm{CO}_{3}$ & 650 & 165 & 29.6 \\
\hline $\mathrm{K}_{2} \mathrm{CO}_{3}$ & 700 & 668 & 30.0 \\
\hline $\mathrm{K}_{2} \mathrm{CO}_{3}$ & 750 & 1030 & 23.2 \\
\hline $\mathrm{K}_{2} \mathrm{CO}_{3}$ & 800 & 1541 & 17.4 \\
\hline
\end{tabular}

\footnotetext{
${ }^{\text {a }}$ Carbon products obtained from chemical activation of 15 wt. $\% \mathrm{KOH}$ and $37.5 \mathrm{wt} . \% \mathrm{~K}_{2} \mathrm{CO}_{3}$, respectively, and various activation temperatures, followed by soaking time of $1 \mathrm{~h}$ under flow of $\mathrm{CO}_{2}$.
} 

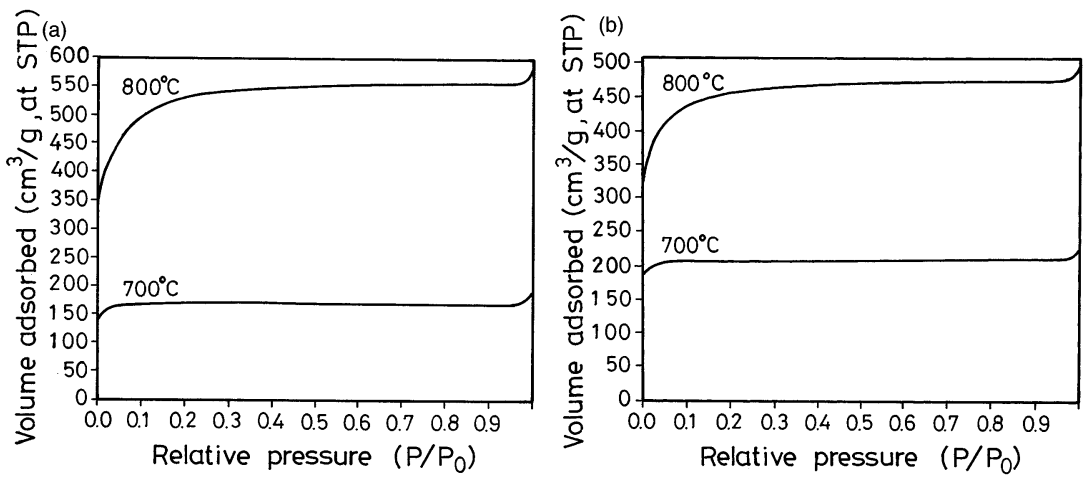

Fig. 2. Adsorption isotherms of nitrogen of the resulting activated carbons produced by chemical activation at activation temperatures of 700 and $800^{\circ} \mathrm{C}$, impregnation ratios of (a) $15 \mathrm{wt} . \% \mathrm{KOH}$ and (b) 37.5 wt. $\% \mathrm{~K}_{2} \mathrm{CO}_{3}$, followed by physical activation in $\mathrm{CO}_{2}$ with soaking time of $1 \mathrm{~h}$.

pyrolysis yields of resulting activated carbons are in the ranges of $12.8-31.3$ and $17.4-33.5 \%$ for $\mathrm{KOH}$ and $\mathrm{K}_{2} \mathrm{CO}_{3}$ series, respectively. The pyrolysis yield was observed to decrease with higher activation temperatures, which is possibly attributed to the evolution of gaseous products and the volatilization of tar products from the carbonaceous structure at higher activation temperatures.

The data in Table 3 present the related physical characteristics of some carbon products and commercial activated carbons, such as total pore volume $\left(V_{t}\right.$, in $\left.\mathrm{cm}^{3} / \mathrm{g}\right)$, true density $\left(\rho_{\mathrm{s}}\right.$, in $\left.\mathrm{g} / \mathrm{cm}^{3}\right)$ and particle density $\left(\rho_{\mathrm{p}}\right.$, in $\left.\mathrm{g} / \mathrm{cm}^{3}\right)$. The results reveal the following points.

1. The values of total pore volume increase rapidly with increase in the activation temperature, which is consistent with the trend of BET surface area in Table 2. It is noted that the maximum values (i.e. 0.87 and $0.74 \mathrm{~cm}^{3} / \mathrm{g}$ for $15 \mathrm{wt} . \% \mathrm{KOH}$ and 37.5 wt. $\% \mathrm{~K}_{2} \mathrm{CO}_{3}$ activated carbons, respectively) of total pore volume at $800^{\circ} \mathrm{C}$ are larger than those (i.e. 0.60 and $0.52 \mathrm{~cm}^{3} / \mathrm{g}$ for BPL and PCB, respectively) of commercial activated carbons (Tsai and Chang, 1994a,b).
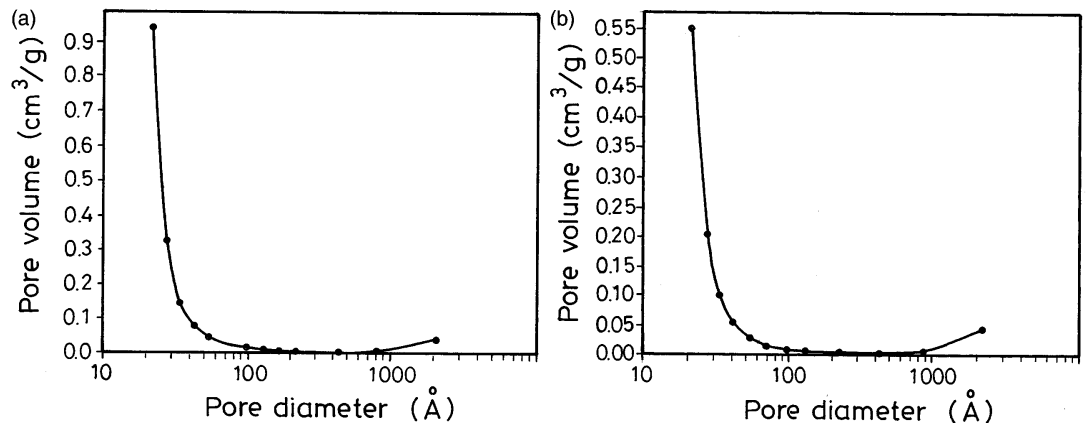

Fig. 3. Pore size distribution of the resulting activated carbons produced by chemical activation at activation temperature of $800^{\circ} \mathrm{C}$, impregnation ratios of (a) $15 \mathrm{wt} . \% \mathrm{KOH}$ and (b) $37.5 \mathrm{wt} . \% \mathrm{~K}_{2} \mathrm{CO}_{3}$, followed by physical activation in $\mathrm{CO}_{2}$ with soaking time of $1 \mathrm{~h}$. 
Table 3

Comparisons on total pore volume, densities and porosity of the resulting carbon products and commercial activated carbons

\begin{tabular}{lllll}
\hline Activated carbon & $\begin{array}{l}\text { Total pore volume } \\
V_{\mathrm{t}}, \mathrm{cm}^{3} / \mathrm{g}\end{array}$ & $\begin{array}{l}\text { True density } \\
\rho_{\mathrm{s}}, \mathrm{g} / \mathrm{cm}^{3}\end{array}$ & $\begin{array}{l}\text { Particle density } \\
\rho_{\mathrm{p}}, \mathrm{g} / \mathrm{cm}^{3}\end{array}$ & Porosity $^{\mathrm{c}} \varepsilon_{\mathrm{p}}$ \\
\hline 15 wt.\% $\mathrm{KOH}-700^{\circ} \mathrm{C}^{\mathrm{d}}$ & 0.26 & 1.89 & 1.26 & 0.33 \\
15 wt. $\% \mathrm{KOH}-750^{\circ} \mathrm{C}$ & 0.48 & 2.05 & 1.03 & 0.50 \\
15 wt. $\% \mathrm{KOH}-800^{\circ} \mathrm{C}$ & 0.87 & 2.47 & 0.78 & 0.68 \\
37.5 wt. $\% \mathrm{~K}_{2} \mathrm{CO}_{3}-700^{\circ} \mathrm{C}$ & 0.32 & 1.88 & 1.17 & 0.38 \\
37.5 wt. $\% \mathrm{~K}_{2} \mathrm{CO}_{3}-750^{\circ} \mathrm{C}$ & 0.49 & 2.05 & 1.02 & 0.50 \\
37.5 wt. $\% \mathrm{~K}^{2} \mathrm{CO}-800^{\circ} \mathrm{C}$ & 0.74 & 2.42 & 0.86 & 0.64 \\
$\mathrm{BPL}^{\mathrm{e}}$ & 0.60 & 2.24 & 0.79 & 0.64 \\
$\mathrm{PCB}^{\mathrm{e}}$ & 0.52 & 2.22 & 0.88 & 0.60 \\
\hline
\end{tabular}

a The true density $\left(\rho_{\mathrm{s}}\right)$ was measured by a helium displacement method with a pycnometer (Lowell and Shields, 1991).

${ }^{\mathrm{b}}$ The particle density $\left(\rho_{\mathrm{p}}\right)$ is calculated from the total pore volume $\left(V_{\mathrm{t}}\right)$ and true density $\left(\rho_{\mathrm{s}}\right)$ (Smith, $1981)$, i.e. $\rho_{\mathrm{p}}=1 /\left(V_{\mathrm{t}}+1 / \rho_{\mathrm{s}}\right)$

${ }^{\mathrm{c}}$ The particle porosity $\left(\varepsilon_{\mathrm{p}}\right)$ is computed from the true density $\left(\rho_{\mathrm{s}}\right)$ and particle density $\left(\rho_{\mathrm{p}}\right)$, i.e. $\varepsilon_{\mathrm{p}}=1-\rho_{\mathrm{p}} / \rho_{\mathrm{s}}$.

${ }^{\mathrm{d}}$ Carbon products obtained from chemical activation at impregnation ratio of $15 \mathrm{wt} . \% \mathrm{KOH}$ and activation temperature of $700^{\circ} \mathrm{C}$, followed by soaking time of $1 \mathrm{~h}$ under flow of $\mathrm{CO}_{2}$.

${ }^{\mathrm{e}}$ BPL and PCB, purchased from Calgon Carbon Co. (USA), have been described earlier (Tsai and Chang, 1994a,b).

2. The decrease in the particle density with the activation temperature is the result of progress of activation as more carbon atoms are reacted at high temperature (Ahmadpour and Do, 1996). However, carbon products with high true density and porosity are produced at high temperature. These results may be explained as follow (Ahmadpour and Do, 1997). With the impregnation ratios studied in this work (i.e. 15 wt. $\% \mathrm{KOH}$ and 37.5 wt. $\% \mathrm{~K}_{2} \mathrm{CO}_{3}$ ), the inhibition of tar as a result of crosslinking (condensation) reaction is more pronounced than the removal of gaseous products in the sample structure at higher temperatures, thus increasing the true density of sample.

The results of ultimate analysis of corn cob and some resulting activated carbons are given in Table 4. The resulting activated carbons with larger surface area contain higher weight percentages of carbon element, which are obviously larger than those (i.e. $42-46$ wt.\%) of raw precursors. Also seen from Table 4, the carbon products prepared from the activation temperature of $800^{\circ} \mathrm{C}$ contain nearly $90 \mathrm{wt} . \%$ of carbon element, which is approximate to those of commercial activated carbons BPL and PCB with BET surface areas of 1028 and $1012 \mathrm{~m}^{2} / \mathrm{g}$, respectively. On the other hand, the hydrogen and oxygen elements are mostly removed in a gaseous form (e.g. $\mathrm{CO}_{2}, \mathrm{H}_{2}$ and $\mathrm{CO}$ ) during the chemical/physical activation, resulting in low analysis values for these elements (Wigmans, 1989). 
As a preliminary evaluation, the economic feasibility of the process proposed in the present study would depend greatly on the cost paid for the main raw materials (i.e. corn cob and activating agents) and energy consumption. The maximum activation temperature of the proposed process is $800^{\circ} \mathrm{C}$, which is evidently smaller than that of the purely physical activation process, indicating less energy consumption. Further, the cost of chemicals (i.e. potassium salts and $\mathrm{CO}_{2}$ ) used in the proposed process are not significant when compared with those (e.g. $\mathrm{ZnCl}_{2}$ or $\mathrm{H}_{3} \mathrm{PO}_{4}$ ) used in the industrial process. However, corn cob, although often regarded as an agricultural waste, must bear the cost of transportation and storage. It is also noted that the pollution control of $\mathrm{ZnCl}_{2}$ widely used in the industrial process must be added to the operation cost in the production of activated carbon because of the more stringent regulation standards. The demand of activated carbon, on the other hand, is growing due to the environmental regulations that call for significantly lower level of pollution emissions (Silverberg, 1999).

\section{Conclusion}

A series of activated carbons were prepared from the combination of chemical and physical activation of agricultural waste corn cob with two activating agents $\mathrm{KOH} / \mathrm{K}_{2} \mathrm{CO}_{3}$ and $\mathrm{CO}_{2}$. The examination of effect of activation temperature on the characterizations of resulting carbon products at the impregnation ratios of 15 wt. $\% \mathrm{KOH}$ and $37.5 \mathrm{wt} . \% \mathrm{~K}_{2} \mathrm{CO}_{3}$ reveals that high activation temperature is better

Table 4

Comparisons on major element analysis of the corn cobs, resulting carbon products and commercial activated carbons

\begin{tabular}{|c|c|c|c|c|}
\hline \multirow[b]{2}{*}{ Samples } & \multicolumn{4}{|c|}{ Unit wt.\% } \\
\hline & $\mathrm{C}$ & $\mathrm{H}$ & $\mathrm{N}$ & $\mathrm{O}$ (by difference) \\
\hline Corn cob-unimpregnated ${ }^{\mathrm{a}}$ & 45.21 & 6.12 & 0.94 & 47.73 \\
\hline Corn cob- 15 wt. $\% \mathrm{KOH}^{\mathrm{b}}$ & 42.64 & 6.06 & 1.00 & 50.30 \\
\hline Corn cob-37.5 wt. $\% \mathrm{~K}_{2} \mathrm{CO}_{3}$ & 44.61 & 5.92 & 0.94 & 48.53 \\
\hline Carbon product- 15 wt. $\% \mathrm{KOH}-700^{\circ} \mathrm{C}^{\mathrm{c}}$ & 82.74 & 1.72 & 2.22 & 13.32 \\
\hline Carbon product- 15 wt. $\% \mathrm{KOH}-800^{\circ} \mathrm{C}$ & 89.20 & 0.77 & 0.54 & 9.49 \\
\hline Carbon product- 37.5 wt. $\% \mathrm{~K}_{2} \mathrm{CO}_{3}-500^{\circ} \mathrm{C}$ & 76.87 & 2.99 & 1.66 & 18.48 \\
\hline Carbon product- 37.5 wt. $\% \mathrm{~K}_{2} \mathrm{CO}_{3}-800^{\circ} \mathrm{C}$ & 85.11 & 0.99 & 1.58 & 12.32 \\
\hline Commercial activated carbon-BPL ${ }^{\mathrm{d}}$ & 87.88 & 0.50 & 0.55 & 11.07 \\
\hline Commercial activated carbon- $\mathrm{PCB}^{\mathrm{d}}$ & 94.85 & 0.68 & 0.11 & 4.36 \\
\hline
\end{tabular}

\footnotetext{
${ }^{\text {a }}$ Reference Tsai et al. (1998).

${ }^{\mathrm{b}}$ Impregnation ratio of $15 \mathrm{wt} . \% \mathrm{KOH}$.

${ }^{\mathrm{c}}$ The particle porosity $\left(\varepsilon_{\mathrm{p}}\right)$ is computed from the true density $\left(\rho_{\mathrm{s}}\right)$ and particle density $\left(\rho_{\mathrm{p}}\right)$, i.e. $\varepsilon_{\mathrm{p}}=1-\rho_{\mathrm{p}} / \rho_{\mathrm{s}}$.

${ }^{\mathrm{d}}$ Carbon products obtained from chemical activation at impregnation ratio of $15 \mathrm{wt} . \% \mathrm{KOH}$ and activation temperature of $700^{\circ} \mathrm{C}$, followed by soaking time of $1 \mathrm{~h}$ under flow of $\mathrm{CO}_{2}$, reference Tsai et al. (1994a,b).
} 
than low activation temperature with respect to the porosity development and the BET surface area/total pore volume, especially in the temperature increase from 650 to $700^{\circ} \mathrm{C}$. The carbon products obtained from the activation temperature of $800^{\circ} \mathrm{C}$ possess large BET surface areas of 1806 and $1541 \mathrm{~m}^{2} / \mathrm{g}$ for the impregnation ratios of 15 wt. $\% \mathrm{KOH}$ and 37.5 wt. $\% \mathrm{~K}_{2} \mathrm{CO}_{3}$, respectively, compared to those of commercial activated carbons. Due to their large adsorption capacity (i.e. BET surface area and total pore volume), low cost (i.e. agricultural waste) and cleaner production process (i.e. $\mathrm{KOH} / \mathrm{K}_{2} \mathrm{CO}_{3}$ versus $\mathrm{ZnCl}_{2} / \mathrm{H}_{3} \mathrm{PO}_{4}$ ), the corn cob-derived activated carbon products offer potential as a precursor substitute for activated carbon.

\section{Acknowledgements}

This research was supported by NSC (National Science Council), Taiwan, under contract number NSC 87-2211-E-041-005.

\section{References}

Aggarwal P, Dollimore D. Production of active carbon from corn cobs by chemical activation. J Thermal Anal 1997;50:525-31.

Ahmadpour A, Do DD. The preparation of active carbons from coal by chemical and physical activation. Carbon 1996;34:471-9.

Ahmadpour A, Do DD. The preparation of activated carbon from macadamia nutshell by chemical activation. Carbon 1997;35:1723-32.

Al-Duri B. Introduction to adsorption. In: McKay G, editor. Use of Adsorbents for the Removal of Pollutants from Wastewaters. Boca Raton, FL: CRC Press, 1996:1-6.

Bagby MO, Widstrom NW. Biomass uses and conversions. In: Watson SA, Ramstad PE, editors. Corn: Chemistry and Technology. St. Paul, MN: American Association of Cereal Chemists, 1987:575-90.

Bansal RC, Donnet JB, Stoeckli F. Active Carbon. New York: Marcel Dekker, 1988:1-26.

Chang CF, Chang CY, Lee SL, Wang SY, Chiang PC, Tseng SK, Tsai WT. Effect of physical carbonization and activation methods on the preparation of activated carbon from corn cob. J Chin Inst Environ Eng 1998;8:227-32.

Gregg SJ, Sing KSW. Adsorption, Surface Area and Porosity, second ed. New York: Academic Press, 1982:195-228.

Heschel W, Klose E. On the suitability of agricultural by-products for the manufacture of granular activated carbon. Fuel 1995;74:1786-91.

Jankowska H, Swiatkowski A, Choma J. Active Carbon. New York: Ellis Horwood, 1991:29-52.

Laine J, Calafat A. Factors affecting the preparation of activated carbons from coconut shell catalized by potassium. Carbon 1991;29:949-53.

Lin JL, Keener HM, Essenhigh RH. Pyrolysis and combustion of corncobs in a fluidized bed: measurement and analysis of behavior. Combust Flame 1995;100:271-82.

Lowell S, Shields JE. Powder Surface Area and Porosity, third ed. London: Chapman \& Hall, 1991:227-30.

Mckillip WJ, Sherman E. Furan derivatives. In: Grayson M, editor. Kirk-Othmer Encyclopedia of Chemical Technology, vol. 11, third ed. New York: Wiley, 1980:499-527.

Noll KE, Gounaris V, Hou WS. Adsorption Technology for Air and Water Pollution Control. Chelsea: Lewis Publishers, 1992:1-12. 
Otowa T, Tanibata R, Itoh M. Production and adsorption characteristics of MAXSORB: high-surface area active carbon. Gas Sep Purif 1993;7:241-5.

Perotti NI, Molina OE. Corn cob as a bacterial substrate for the production of forage protein. Biol Wastes 1988;26:125-31.

Pollard SJT, Fowler GD, Sollars CJ, Perry R. Low-cost adsorbents for waste and wastewater treatment: a review. Sci Total Environ 1992;116:31-52.

Silverberg P. Activated carbon for the 'hole' cleanup job. Chem Eng Dec 1999;105:33-7.

Smith JM. Chemical Engineering Kinetics, third ed. New York: McGraw-Hill, 1981:334-8.

Tsai WT, Chang CY. Adsorption of methylene chloride vapor on activated carbons. J Chem Tech Biotechnol 1994a;61:145-51.

Tsai WT, Chang CY. Surface chemistry of activated carbons and its relevance for effects of relative humidity on adsorption of chlorinated organic vapors. Chemosphere 1994b;29:2507-15.

Tsai WT, Chang CY, Lee SL. Preparation and characterization of activated carbons from corn cob. Carbon 1997;35:1198-200.

Tsai WT, Chang CY, Lee SL. A low cost adsorbent from agricultural waste corn cob by zinc chloride activation. Bioresour Technol 1998;64:211-7.

Wigmans T. Industrial aspects of production and use of activated carbons. Carbon 1989;27:13-22. 